For personal use only. Not to be reproduced without permission of the publisher (editorial@gabi-journal.net).

\section{Health authority perspective on biosimilars}

Brian Godman, BSC, PhD

\section{Dr Brian Godman reviews Mr Gustaf Befrits' paper on the case for biosimilars from a payer's perspective. Biosimi- lars are increasingly important to payers with growing resource pressures. However, key issues need addressing to fully capture their benefits.}

Keywords: Biosimilars, economics, payer

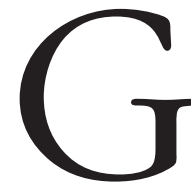

ustaf Befrits has provided us with an important insight into biosimilars from a payer's perspective [1]. Key areas include the fact that healthcare systems are under increasing resource pressures due to well-known factors, including an ageing population, stricter clinical treatment targets and the continued launch of new premium priced drugs $[2,3]$. The latter includes new biological drugs, with almost 300 identified in a quick internet search [1]. These can cost up to US\$25,000/patient/month [4], in part, due to the complexity of production [1]. Their costs have become more visible in recent years with many standard oral drugs now available as low cost generics $[2,3]$. Sweden has seen low prices for generics with mandatory generics substitution with the lowest cost generics [1, 3], and more recently with monthly auctions [3]. Demand-side measures have also appreciably enhanced the prescribing of generics versus patented products in a class or related class [2, 3]. As pointed out, this builds on the accepted premise of substitution as well as similarity of the products in a class [1]. However, further reforms are needed [1].

Consequently, as noted by Befrits, biosimilars are an attractive proposition among payers to create headroom for increased volumes as well as new premium priced drugs, acknowledging that price reductions will not be of the same magnitude as with small molecule oral drugs. This is in view of the complexities involved with their production process as well as clinical trial and post-marketing surveillance requirements [1]. Prices for small molecule oral generics can be as low as $4 \%$ of the originator price in Sweden [3]. Typically, price reductions for biosimilars are not as great, averaging between $15 \%$ to $30 \%$ of the originator price in both Europe and US [5, 6]. In Austria, price reductions are $48 \%$ for the first multiple sourced biosimilar; mirroring the situation for small molecule oral generics [2]. As a result of the high prices of originators, there is considerable potential to save costs even at these discounts [6, 7]. In Europe, projected sales for filgrastim (with six biosimilars) are envisaged to exceed those of Neupogen (originator) during 2012 at US\$156 million vs US\$129 million for the originator [5]. Overall, biosimilars are expected to save between Euros 11.8 billion and Euros 33.4 billion between 2007 and 2020 across a range of European countries [7]. This will be helped by the growing number of biosimilars-14 approved for marketing by the European Medicines Agency by mid-2012 [8].

However, a number of key issues need to be addressed or else it will be increasingly difficult for health authorities in Europe to maintain comprehensive and equitable health care, argues Befrits. Otherwise, there could be negative attitudes towards new expensive biological drugs [1].
One major issue highlighted is substitutability. Currently, there is typically no substitution among ambulatory care pharmacies in Europe, enhanced by recent EU pharmacovigilance legislation that came into effect in July 2012 [8, 9]. This is due to differences in manufacturing processes, and biosimilars cannot be assumed to share an identical safety profile with the originator [8]. Compulsory international non-proprietary name prescribing is also waivered for biopharmaceutical products [10]. The only exception is Germany where there is currently a short list of 'bioidenticals' that can be substituted [11]. This came into effect in October 2011. These products can be substituted as their production processes are considered identical. There are also prescribing targets for biosimilars among physicians in Germany [12].

Data on the frequency of switching is scarce, although seen most frequently with erythropoietins [13]. A recent study found no evidence from trials or post-marketing surveillance that switching to and from different biopharmaceuticals leads to safety concerns [13], with similar safety profiles between recombinant erythropoietins [14]. However, others have concerns [8]. Confidence in biosimilars should be enhanced by recent tightening on EU regulations [8] as well as further studies in this area [14]

In conclusion, Befrits highlights key issues surrounding biosimilars. As mentioned, there is an urgent need among health authorities and health insurance companies to enhance the utilisation of biosimilars at prices acceptable to all key stakeholder groups. This will build on current measures in Austria and Germany, as well as potential activities and incentives [15]. This will be explored further in future articles.

\section{Competing interests: None.}

Provenance and peer review: Commissioned; internally peer reviewed.

\footnotetext{
References

1. Befrits $G$. The case for biosimilars-a payer's perspective. Generics and Biosimilars Initiative Journal (GaBI Journal). 2013;2(1):12. doi:10.5639/gabi. 2013.0201 .010
} 
2. Godman B, Wettermark B, Bishop I, Burkhardt T, Fürst J, et al. European payer initiatives to reduce prescribing costs through use of generics. Generics and Biosimilars Initiative Journal (GaBI Journal).2012;1(1):22-7. doi:10.5639/gabij. 2012. 0101.007

3. Godman B, Abuelkhair M, Vitry A, Abdu S, et al. Payers endorse generics to enhance prescribing efficiency; impact and future implications, a case history approach. Generics and Biosimilars Initiative Journal (GaBI Journal). 2012;1(2):69-83. doi:10.5639/gabij.2012.0102.017

4. Kaiser J. Personalized medicine. New cystic fibrosis drug offers hope, at a price. Science. 2012 Feb 10;335(6069):645.

5. Reinke T. Biosimilars might not measure up to health plan expectations. Manag Care. 2012 Oct; 21(10):12-3.

6. Declerck P, Simoens S. A European perspective on the market accessibility of biosimilars. Biosimilars. 2012;2:33-40.

7. Höer H, de Millas C, Häussler B, Haustein R. Saving money in the European healthcare systems with biosimilars. Generics and Biosimilars
Initiative Journal (GaBI Journal). 2012;1(3-4). 120-6. doi:10.5639/gabij.2012.0103-4.036

8. Clayton J. Tighter EU rules on pharmacovigilance for biologicals. Generics and Biosimilars Initiative Journal (GaBI Journal). 2012;1(2):56-7. doi: 10.5639/gabij.2012.0102.015

9. Rovira J, Espin J, Garcia L, de Labry A. The impact of biosimilars' entry in the EU market. EMIN€T January 2011. 2011 [cited 2013 Feb 4]. Available from: http://ec.europa.eu/enterprise/sectors/ healthcare/files/docs/biosimilars_market_012011_ en.pdf

10. Garuoliene K, Godman B, Gulbinoviĉ J, Wettermark B, Haycox A. European countries with small populations can obtain low prices for drugs: Lithuania as a case history. Expert Rev Pharmacoecon Outcomes Res. 2011 Jun;11(3):343-9.

11. Anon. Anlage 1 zum Rahmenvertrag nach $\S 129$ SGB V zu § 4 Absatz 1 Buchstabe a). 2011 [cited 2013 Feb 4]. German. Available from: http://www.pharmatrix.de/cms/upload/pdf/Recht/apothekenrecht/ Rahmenvertrag_129_Abs_2_Anlage_1_111001.pdf

12. Kassenärztliche Bundesvereinigung. Rahmenvorgaben nach $\S 84$ Abs. 7 SGB V - Arzneimittel - für das Jahr 2012 vereinbart zwischen dem Spitzenverband Bund der Krankenkassen (GKVSpitzenverband) und der Kassenärztlichen Bundesereinigung - nachstehend Bundesvertragspartner genannt - Bekanntgaben der Herausgeber: Kassenärztliche Bundesvereinigung; Dtsch Arztebl 2011;108(47): A-2565/B-2145/C-2117. [cited 2013 Feb 4]. German. Available from: http://m.aerzteblatt.de/print/114221.htm

13. Ebbers $H$, Muenzberg $M$, Schellekens $H$. The safety of switching between therapeutic proteins. Expert Opin Biol Ther. 2012;12(11): 1473-85.

14. Abraham I, MacDonald K. Clinical safety of biosimilar recombinant human erythropoietins. Expert Opin Drug Saf. 2012;11:819-40.

15. Mackay T, Liang B. Promoting access to biosimilars: a public-private partnership model for biosimilar development in underserved populations. Generics and Biosimilars Initiative Journal (GaBI Journal). 2012;1(2):84-8. doi:10.5639/gabij. 2012.0102.018

DOI: $10.5639 /$ gabij.2013.0201.010

Copyright @ 2013 Pro Pharma Communications International 